\title{
First confirmed record of the occurrence of the lesser devil ray, Mobula hypostoma (Elasmobranchii, Mobulidae), in the southwestern Gulf of Mexico
}

\author{
Luis Fernando Del Moral-Flores ${ }^{1}$, Itzel Meza-Abundio ${ }^{1}$ \& Horacio Pérez-España ${ }^{2}$ \\ ${ }^{1}$ Laboratorio de Zoología, Facultad de Estudios Superiores Iztacala, Universidad Nacional Autónoma de \\ México (UNAM), Tlalnepantla, Estado de México, México \\ ${ }^{2}$ Instituto de Ciencias Marinas y Pesquerías, Universidad Veracruzana, Boca del Río, Veracruz, México \\ Corresponding author: Luis Del Moral (delmoralfer@ comunidad.unam.mx)
}

\begin{abstract}
Nine specimens (one female and eight males, all juveniles) of lesser devil ray, Mobula hypostoma (Bancroft, 1831), were caught in the southwest Gulf of Mexico. These specimens represent the first record of the species in the Mexican waters. The disk width ranged between 552 and $773 \mathrm{~mm}$. Morphometrics data are consistent with previously published records. Because of the number of specimens captured, we suggest that it is not a rare species in the southwest Gulf of Mexico.
\end{abstract}

Keywords: Mobula hypostoma; Chondrichthyes; devil ray; distribution; morphometry; western Atlantic

The family Mobulidae is a group of planktivorous and piscivorous elasmobranchs. They were commonly known as mantas or devil rays that are widely distributed in temperate, tropical, and subtropical waters of all oceans (Couturier et al., 2012). They are large chondrichthyans with a lobe on each side of the head, pectoral fins as wings, terminal mouth and a tail without a stinger, ranging in disc width from 100 to 700 $\mathrm{cm}$ (Notarbartolo-di-Sciara, 1987; McClain et al., 2015). Devil rays have peculiar patterns in their life histories; their reproductive aspects, and coupled with inadequate fisheries management, make them prone to some state of risk (Couturier et al., 2012). Therefore, it is necessary, despite having charismatic representatives, to implement strategies that will help their conservation (Lawson et al., 2017).

Nowadays, the family Mobulidae is represented by nine valid species grouped in a single genus, Mobula Rafinesque, 1810 (White et al., 2018). However, the taxonomic situation of this family has been complex; previously, the genus Manta Bancroft, 1829, was recognized as valid based on the terminal position of the mouth (Marshall et al., 2009). Moreover, recent studies suggest a cryptic species distributed in the Caribbean region (Marshall et al., 2009; HinojosaAlvarez et al., 2016), sympatric with three other valid species (Mobula sp., M. birostris and M. mobular).
Mobula hypostoma (Bancroft, 1831), locally known as "maroma", is distributed on both coasts of the Atlantic Ocean. In the western Atlantic, its estimated distribution includes tropical and subtropical coastal waters. From Mar del Plata in Argentina to Cape Lookout, North Carolina in the USA, including the Caribbean Sea and the Gulf of Mexico (Notarbartolodi-Sciara, 1987). However, the details of its biology are scarce as well as its distribution; in fact, records of this species in the Gulf of Mexico are sporadic, and there are no valid records of their presence in Mexican waters (Del Moral-Flores et al., 2015). This contribution aims to provide evidence of the presence of M. hypostoma in the southwest portion of the Gulf of Mexico, based on five records and nine specimens collected in these waters, representing the first verified physical record of the species for the country.

During a study on the composition of the chondrichthyans associated with the state of Veracruz's artisanal fisheries, southwestern coast of the Gulf of Mexico, nine individuals of the genus Mobula were captured in May, June, August, September, and October of 2018. The catches were made through beach nets of $700 \mathrm{~m}$ and mesh openings of 2 and 3 inches, on the beach, in Las Barrancas (18 $\left.59 ' 58.4^{\prime \prime} \mathrm{N}, 95^{\circ} 57^{\prime} 55.8^{\prime \prime} \mathrm{W}\right)$, Alvarado, Veracruz. The specimens were frozen and transferred to the Ichthyology Collection of the Zoology Laboratory

Corresponding editor: Leonardo Abitia 
of the Facultad de Estudios Superiores Iztacala (CIFI), Universidad Nacional Autónoma de México (UNAM) for its correct determination using specialized keys (McEachran \& Carvalho, 2002; White \& Last, 2016). Body measurements were taken accor-ding to the Notarbartolo-di-Sciara (1987) protocol, and a series of photographs and a sample of muscle tissue were taken. Subsequently, they were processed curatorially (fixed in 10\% formaldehyde, preserved in 70\% ethyl alcohol) and deposited in CIFI 1411, 1412, and 1413.

The nine specimens, one female and eight males, ranging from 552-773 $\mathrm{mm}$ in disk width were identified as Mobula hypostoma (Atlantic devil ray or "maroma" in Spanish) (Fig. 1) based on the following combination characters (sensu Notarbartolo-di-Sciara, 1987): absence of caudal spine; base of tail depressed laterally; length of the upper and lower dental bands less than 55 and $52 \%$ of the width of the mouth, respectively; small, sub-circular spiracle, ventral to the plane of the pectoral fins; imbricated teeth, with sexual dental dimorphism in adults; first interbranchial distance greater than $13.2 \%$ of disc width (DW); distance from the distal end of the cephalic fin to the spiracle greater than $13.4 \%$ of the DW; preoral distance less than $40 \%$ of DW; and maximum DW of ca. $125 \mathrm{~cm}$. However, large specimens with an DW of 107 to $230 \mathrm{~cm}$ have been recorded in the vicinity of Isla Margarita in Venezuela, these differences in size, as suggested by Ehemann et al. (2017), could indicate that these organisms are members of a subspecies of $M$. hypostoma or even an undescribed species restricted to the Caribbean.

Table 1 presents the specimens' morphometric measurements, which agree with those mentioned by Notabartolo-di-Sciara (1987) in their review of the genus Mobula Rafinesque, 1810.

The determination at the species level within Mobula is problematic, due to the morphological similarity and the overlapping distribution of their species (Couturier et al., 2012); moreover, the lack, loss, and destruction suffered by some type specimens have caused some nomenclatural and taxonomic problems and confusions (White et al., 2018). Notarbartolo-diSciara (1987) synonymized the nominal species Ceratobatis robertsii with $M$. hypostoma, and does not consider necessary to designate a neotype for $M$. hypostoma since it is the only known "small" mobula of the western Atlantic; moreover, the same author validated $M$. rochebrunei as proper to the eastern Atlantic. Recently, some gaps in their phylogenetic tree of the genus and family were clarified with the help of molecular data, finding that $M$. roche-brunei is a junior synonym of $M$. hypostoma, which is restricted to the Atlantic Ocean (White et al., 2018).

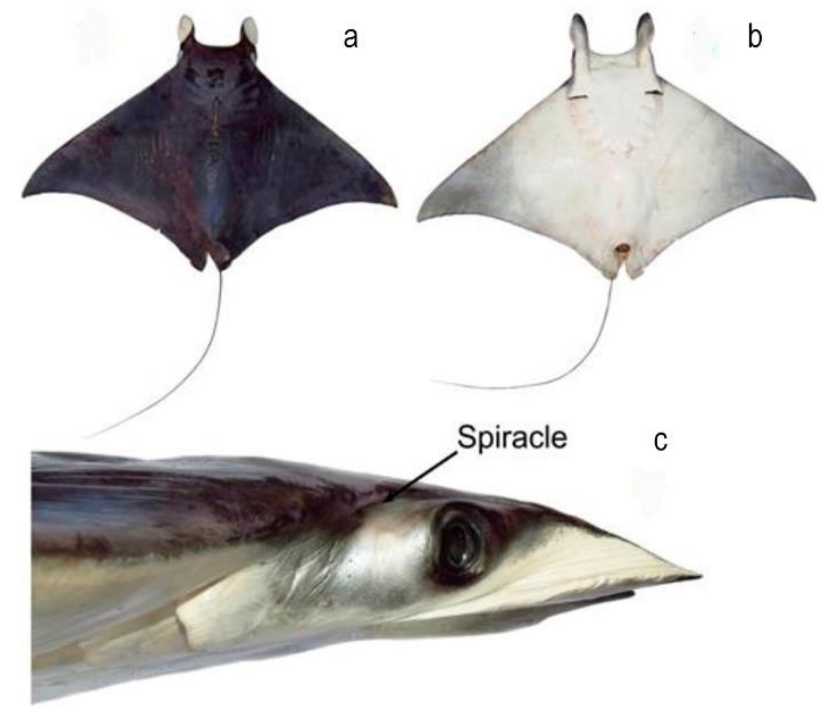

Figure 1. Mobula hypostoma from the southwest Gulf of Mexico (CIFI): a) Dorsal view, b) ventral view, c) the right side of the head region showing that spiracle's openings.

The records of M. hypostoma in the western Atlantic have been deficient and sporadic; there is a summary of its occurrences in Bigelow \& Shroeder (1953) and Notarbartolo-di-Sciara (1987). The Gulf of Mexico records are restricted to the north, being those of the present contribution the first record confirming its presence in the southwest of the Gulf of Mexico. In Mexico there are informal records of the species and its presence has been indicated based on regional faunal lists (Del Moral-Flores et al., 2015; Ehemann et al., 2018); this is the first record of the species in Mexican waters based on and supported by museum material.

The specimens registered in the northern Gulf of Mexico, have been juveniles: Alabama (USNM 197409, a juvenile male with $666 \mathrm{~mm}$ disk width) and Louisiana (USNM 205397, a juvenile male with 717 mm DW), USA (Notarbartolo-di-Sciara, 1987). The sizes are similar to the interval observed in the captured specimens (552-773 $\mathrm{mm} \mathrm{DW}$ ) in the southeast of the Gulf of Mexico, and they did not present developed or calcified claspers, which could indicate the possibility that in the Gulf of Mexico, there are areas with favorable conditions to serve as areas of birth or aging. Although for the majority of the mobulids, their ecological and distribution patterns in the juvenile state are unknown, the biology of $M$. hypostoma is practically unknown (Couturier et al., 2012). There is evidence in the northeastern part of the Gulf of Mexico, in the National Marine Sanctuary of Flower Garden Banks, and surrounding areas, which mark it as a breeding area for both the giant stingray (Mobula birostris) and the reef stingray (Mobula cf. birostris) (Childs, 2001; Stewart et al., 2018). The delimitation of the 
Table 1. Morphometrics, expressed in percentage of the disk width, of the nine specimens of Mobula hypostoma. Annotations. Sex M: males; F: females. DW: disc width, DL: disc length, AP: anterior projection, MRMp: from the midpoint of rostral margin to free rear tip of the pelvic fin, PD: predorsal distance, DB: dorsal fin base length, DH: dorsal fin height, PrD: precloacal distance, TL: tail length, 1GL: 1st-gill opening length; 2GL: 2nd-gill opening length; 3GL: 3rd-gill opening length; 4GL: 4th-gill opening length; 5GL: 5th-gill opening length,1ID: first interbranchial distance; 2ID: fifth interbranchial distance, R1G: from the midpoint of rostral margin to transverse line of 1st-gill openings; R5G: from the midpoint of rostral margin to the transverse line of 5th-gill openings, PFL: pelvic fin length, CFL: cephalic fin length, CFW: cephalic fin width, DE: diameter of the eyeball: CW: cranial width, PL: preoral length, HL: head length, MW: mouth width, ID: internarial distance, UTL: upper tooth band length, LTL: lower tooth band length.

\begin{tabular}{lcccccccccc}
\hline Measurement/Sex & $\mathrm{F}$ & $\mathrm{M}$ & $\mathrm{M}$ & $\mathrm{M}$ & $\mathrm{M}$ & $\mathrm{M}$ & $\mathrm{M}$ & $\mathrm{M}$ & $\mathrm{M}$ & Range \% AD \\
\hline DW & 578 & 707 & 605 & 607 & 610 & 613 & 594 & 773 & 552 & \\
DL & 312 & 357 & 304 & 311 & 319 & 323 & 325 & 380 & 287 & $49.2-54.7$ \\
AP & 236 & 242 & 254 & 228 & 258 & 243 & 254 & 250 & 230 & $32.3-42.8$ \\
MRMp & 324 & 363 & 308 & 316 & 323 & 328 & 327 & 385 & 293 & $49.8-56.1$ \\
PD & 270 & 307 & 273 & 270 & 282 & 284 & 286 & 327 & 251 & $42.3-48.1$ \\
DB & 31.9 & 48 & 30.3 & 33.4 & 33.9 & 35.3 & 34.8 & 46.4 & 28 & $5.0-6.8$ \\
DH & 31 & 36 & 23.9 & 27 & 24.5 & 23 & 24.6 & 30.2 & 19 & $3.4-5.4$ \\
PrD & 247 & 301 & 256 & 250 & 271 & 274 & 262 & 306 & 242 & $39.6-44.7$ \\
TL & 433 & 521 & 448 & 427 & 449 & 436 & 398 & s/c & 400 & $67.0-74.9$ \\
1GL & 41 & 49 & 29.9 & 30.9 & 33.5 & 32.2 & 35.3 & 39.2 & 30 & $4.9-7.1$ \\
2GL & 29.5 & 51 & 32 & 35 & 32.9 & 34.7 & 36 & 41.9 & 31 & $5.1-7.2$ \\
3GL & 30.7 & 52 & 33.1 & 34.5 & 34.6 & 36.4 & 36.1 & 42.2 & 32 & $5.3-7.4$ \\
4GL & 39 & 52 & 31.7 & 32.4 & 31.9 & 33.6 & 33.7 & 40 & 29 & $5.2-7.4$ \\
5GL & 22.7 & 42 & 23.1 & 22.5 & 23.8 & 24.8 & 20.6 & 29.7 & 21 & $3.5-5.9$ \\
1ID & 87 & 106 & 92 & 93 & 92.4 & 96 & 93 & 97.9 & 73 & $12.7-15.7$ \\
2ID & 20.1 & 35 & 32 & 31 & 30 & 32 & 32 & 25.1 & 21 & $3.2-5.4$ \\
R1G & 74 & 80 & 78 & 78 & 80 & 82 & 79 & 83 & 62 & $10.7-13.4$ \\
R5G & 132 & 156 & 138 & 139 & 147 & 148 & 138 & 177 & 126 & $22.1-24.1$ \\
PFL & 70 & 77 & 69 & 71 & 70 & 72 & 65 & 76.6 & 47 & $8.5-12.1$ \\
CFL & 72 & 111 & 72.6 & 71.6 & 75.1 & 75.6 & 74.4 & 90.8 & 63 & $11.4-15.7$ \\
CFW & 24.6 & 38 & 22 & 24.8 & 25.9 & 30.8 & 23.5 & 31.1 & 22 & $3.6-5.4$ \\
DE & 10.1 & 14 & 10.9 & 12.6 & 13 & 11 & 12.8 & 13.6 & 12 & $1.7-2.2$ \\
CW & 111 & 146 & 132 & 131 & 126 & 114 & 144 & 138 & 106 & $17.9-24.2$ \\
PL & 20.5 & 36 & 22.7 & 21.8 & 22.2 & 22.8 & 21.8 & 26.5 & 22 & $3.4-5.1$ \\
HL & 70.6 & 107 & 78.9 & 80.5 & 82.4 & 83.1 & 81.9 & 99.7 & 61 & $11.1-15.1$ \\
MW & 68.1 & 95 & 75.6 & 72.8 & 71.4 & 74.8 & 73.4 & 91.1 & 62 & $11.2-13.4$ \\
ID & 67 & 88 & 65.4 & 63.4 & 65.5 & 66.6 & 65.6 & 77.2 & 57 & $10.0-12.4$ \\
UTL & 38.7 & 38.17 & 36.6 & 33.6 & 35.4 & 36.2 & 32.8 & 42.8 & 29 & $5.3-6.7$ \\
LTL & 33.5 & 38.68 & 37.4 & 36.1 & 36.5 & 37.1 & 34.9 & 43.5 & 27 & $4.9-6.2$ \\
\hline & & & & & & & & & &
\end{tabular}

breeding areas requires criteria to be met; it is important for future studies of their life cycles and considers management strategies and the correct conservation of shark and ray species (Heupel et al., 2007).

\section{REFERENCES}

Bigelow, H.B. \& Schroeder, W.C. 1953. Sharks, sawfishes, guitarfishes, skates and rays. Chimaeroids. In: Tee-Van, J., Breder, C.M., Hildebrand, S.F., Parra A.E. \& Schroeder, W.C. (Eds.). Fishes of the western north Atlantic. Part 2. Yale University, New Haven.
Couturier, L.I.E., Marshall, A.D., Jaine, F.R.A., Kashiwagi, T., Pierce, S.J., Townsend, K.A., Weeks, S.J., Bennett, M.B. \& Richardson, A.J. 2012. Biology, ecology and conservation of the Mobulidae. Journal of Fish Biology, 80: 1075-1119. doi: 10.1111/j.10958649.2012.03264.x

Childs, J.N. 2001. The occurrence, habitat use, and behavior of sharks and rays associating with topographic highs in the northwestern Gulf of Mexico. [https:// oaktrust.library.tamu.edu/handle/1969.1/ETD-TAMU2001-THESIS-C45]. Reviewed: October 15, 2019.

Del Moral-Flores, L.F., Morrone, J.J., Alcocer Durand, J., Espinosa-Pérez, H. \& Pérez-Ponce de León, G. 2015. 
Lista patrón de los tiburones, rayas y quimeras (Chondrichthyes, Elasmobranchii, Holocephali) de México. Arxius de Miscel-lània Zoològica, 13: 47163. doi: 10.32800/amz.2015.13.0047

Ehemann, N.R., González-González, L.V. \& Trites, W. 2017. Lesser devil rays Mobula cf. hypostoma from Venezuela are almost twice their previously reported maximum size and maybe a new sub-species. Journal of Fish Biology, 90: 1142-1148. doi: 10.1111/jfb. 13252

Ehemann, N.R., González-González, L.V., CholletVillalpando, J.G. \& De La Cruz-Agüero, J. 2018. Updated checklist of the extant chondrichthyes within the Exclusive Economic Zone of Mexico. Zookeys, 774: 17-39. doi: 10.3897/zookeys.774.25028

Heupel, M.R., Carlson, J.K. \& Simpfenddorfer, C.A. 2007. Shark nursery areas: concepts, definition, characterization and assumptions. Marine Ecology Progress Series, 337: 287-297. doi: 10.3354/meps 337287

Hinojosa-Alvarez, S., Walter, R.P., Diaz-Jaimes, P., Galván-Magaña, F. \& Paig-Tran, E.M. 2016. A potential third Manta ray species near the Yucatán Peninsula? Evidence for a recently diverged and novel genetic Manta group from the Gulf of Mexico. PeerJ, 4: e2586. doi: 10.7717/peerj.2586

Lawson, J.M., Fordham, S.V., O'Malley, M.P., Davidson, L.N.K., Walls, R.H.L., Heupel, M.R., et al. 2017. Sympathy for the devil: a conservation strategy for devil and manta rays. PeerJ, 5: e3027. doi: 10.7717/peerj.3027

Marshall, A.D., Compagno, L.J.V. \& Bennett, M.B. 2009. Redescription of the genus Manta with resurrection of Manta alfredi (Krefft, 1868) (Chondrichthyes; Myliobatoidei; Mobulidae). Zootaxa, 2301: 1-28.

Received: 11 November 2019; Accepted: 4 May 2020
McClain, C.R., Balk, M.A., Benfield, M.C., Branch, T.A., Chen, C., Cosgrove, J., et al. 2015. Sizing ocean giants: patterns of intraspecific size variation in marine megafauna. PeerJ, 3: e715. doi: 10.7717/peerj.715

McEachran, J.D. \& De Carvalho, M.R. 2002. Batoid fishes. In: Carpenter, K.E. (Ed.). The living marine resources of the western central Atlantic. FAO, Rome, pp. 508-589.

Notarbartolo-di-Sciara, G. 1987. A revisionary study of the genus Mobula Rafinesque, 1810 (Chondrichthyes: Mobulidae) with the description of a new species. Zoological Journal of the Linnean Society, 91: 1-91. doi: 10.1111/j.1096-3642.1987.tb01723.x

Stewart, J.D., Nuttall, M., Hickerson, E.L. \& Johnston, M.A. 2018. Important juvenile manta ray habitat at Flower Garden Banks National Marine Sanctuary in the northwestern Gulf of Mexico. Marine Biology, 165: 111. doi: 10.1007/s00227-018-3364-5

White, W.T. \& Last, P.R. 2016. Devilrays: Family Mobulidae. In: Last, P.R., White, W.T. \& De Carvalho, M.R., Séret, B., Stehmann, M.F.W. \& Naylor, G.J.P. (Eds.). Rays of the world. Cornell University Press, Melbourne, pp. 741-749.

White, W.T., Corrigan, S., Yang, L., Henderson, A.C., Bazinet, A.L., Swofford, D.L. \& Naylor, G.J.P. 2018. Phylogeny of the manta and devil rays (Chondrichthyes: Mobulidae), with an updated taxonomic arrangement for the family. Zoological Journal of the Linnean Society, 182: 50-75. doi: 10.1093/zoolinnean/ zlx018 